\title{
I.UMIRUNG
}

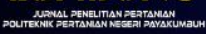

\section{STRATEGI RETAIL MIX DALAM MEMPENGARUHI KEPUTUSAN KONSUMEN BERBELANJA PADA PASAR MODEREN DI KOTA PAYAKUMBUH}

\author{
Alfikri $^{1}$, Darnetti ${ }^{1}$, dan Raeza Firsta Wisra ${ }^{2}$ \\ ${ }^{1}$ Prodi Pengelolaan Agribisnis Politeknik Pertanian Negeri Payakumbuh \\ ${ }^{2}$ Prodi Agribisnis Politeknik Pertanian Negeri Payakumbuh \\ Korespondensi: alfikri.politani@gmail.com
}

$\begin{array}{ll}\text { Diterima } & : 13 \text { November } 2020 \\ \text { Disetujui } & : 26 \text { Februari } 2021 \\ \text { Diterbitkan } & : 28 \text { Februari } 2021\end{array}$

\begin{abstract}
ABSTRAK
Perkembangan pasar moderen di Kota Payakumbuh tidak terlepas dari respon konsumen yang tinggi, walaupun demikian peran strategi retail mix yang di laksanakan oleh manajemen masing-masing pasar moderen dapat menentukan keberlangsungan usaha tersebut, maka penelitian ini akan menganalisis faktor-faktor yang mempengaruhi konsumen untuk berbelanja di pasar moderen dengan variabel bebas yaitu: location $\left(X_{1}\right)$, marcandise assortments $\left(X_{2}\right)$, pricing $\left(X_{3}\right)$, costomer service $\left(X_{4}\right)$, store design and display $\left(X_{5}\right)$, dan communication mix $\left(X_{6}\right)$. Uji instrumen penelitian menggunakan 30 responden, dari uji Validitas didapatkan 1 item tidak valid (LKS-2 pada variabel $\mathrm{X}_{1}$ ) maka dikeluarkan dan uji realibilitas didapatkan nilai cronbach's alpha sebesar 0,953, maka instrumen penelitian dianggap realib karena nilainya lebih besar dari 0,60. dari hasil uji instrumen ini maka penelitian ini dapat menggunakan instrumen ini pada kondisi yang sebenarnya sesuai dengan tujuan penelitian. Hasil analisis dari 118 responden didapatkan bahwa koefisien determinasi sebesar 51,4\%, sedangkan uji hipotesis didapatkan 4 variabel tidak signifikasn yaitu location $\left(X_{1}\right)$, marcandise assortments $\left(X_{2}\right)$, pricing $\left(X_{3}\right)$, costomer service $\left(X_{4}\right)$. kemudian dua variabel signifikan yaitu store design and display $\left(X_{5}\right)$, dan communication mix $\left(X_{6}\right)$. signifikan. Rekomendasi responden untuk memilih minimarket juga terpengaruhi oleh bentuk dan layout minimatket yang memberikan kenyamanan dan tampilan beserta promisi yang dilakukan oleh minimarket berupa plang merek dan iklan-iklan yang dibuat minimarket.
\end{abstract}

\section{Keyword: minimarket, regresi berganda, retail mix}

\begin{abstract}
The development of modern markets in Payakumbuh City is inseparable from high consumer response, however the role of the retail mix strategy carried out by the management of each modern market can determine the sustainability of the business, so this study will analyze the factors that influence consumers to shop at modern markets with independent variables, namely: location $\left(X^{1}\right)$, merchandise assortments $\left(X^{2}\right)$, pricing $\left(X^{3}\right)$, customer service $\left(X^{4}\right)$, store design and display $\left(X^{5}\right)$, and communication mix $\left(X^{6}\right)$. The research instrument test used 30 respondents, from the validity test obtained 1 invalid item (LKS-2 on variable $\left.X^{1}\right)$ then it was issued and the reliability test obtained a cronbach's alpha value of 0.953, so the research instrument was considered realistic because the value was greater than 0.60. From the test results of this instrument, this research can use this instrument in actual conditions in
\end{abstract}




\section{I.UMIBUNG}

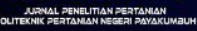

accordance with the research objectives. The results of the analysis of 118 respondents found that the coefficient of determination was $51.4 \%$, while the hypothesis test of four insignificant variables was location $\left(X^{1}\right)$, merchandise assortments $\left(X^{2}\right)$, pricing $\left(X^{3}\right)$, customer service $\left(X^{4}\right)$. then two significant variables, namely store design and display $\left(X^{5}\right)$, and communication mix $\left(X^{6}\right)$. significant. Respondents' recommendations for choosing a minimarket are also influenced by the shape and layout of the mini-kettles that provide comfort and appearance along with the promotion carried out by the minimarkets in the form of brand signs and advertisements made by minimarkets.

\section{Keywords: minimarket, multiple regression, retail mix}

\section{PENDAHULUAN}

Pergeseran pola belanja masyarakat saat sekarang ini yang lebih suka belanja ke ritel moderen atau pasar moderen membuat usaha pasar moderen ini berkembang pesat. Peluang yang cukup besar itu dimanfaatkan para pengusaha untuk mendapatkan keuntungan melalui usaha ini, perkembangan yang pesat tersebut juga mempunyai dampak terhadap persaingan antar usaha pasar moderen itu sendiri dalam menarik pelanggan, sehingga masing-masing usaha ini harus mempunyai strategi yang berbeda-beda pula sesui dengan target yang ingin dicapai oleh usaha tersebut.

Pertumbuhan pasar moderen Kota Payakumbuh pada lima tahun terakhir cukup pesat, saat ini pasar moderen telah menguasai sisi-sisi jalan utama yang sangat strategis di kota ini. Sebaran dari pasar moderen ini berdasarkan jalan utama seperti di Jalan A. Yani Payakumbuh Barat telah berdiri Nabuma Swalayan, Raja Mart 2, Nela dan Cake Mart, kemudian di Jalan Sukarno-Hatta Payakumbuh Utara telah berdiri Ramayana Swalayan, Mega Prima, Raja Mart 1, Niagara Swalayan, Tara Mart, RJ mart, Budiman Swalayan, kemudian di Jalan Tan Malaka Payakumbuh Utara telah beridiri CO-OP Mart dan Karya Putra, selanjutnya di Jalan Sudirman ada Tara Mart, di jalan Ade Irma Suryani ada SM Mart, dan Jalan Rasuna Said Payakumbuh Timur telah berdiri Dede Setia Mart.

Dengan banyaknya pilihan pasar moderen disetiap sisi Kota Payakumbuh membuat pola belanja masyarakat juga akan berubah dengan sidirinya, pola perubahan konsumen dalam menentukan apa yang akan dikonsumsi dipengaruhi oleh faktor langsung berupa faktor psikologis dan karakteritik individual, kemudian faktor tidak langsung berupa faktor lingkungan sosial budaya. Pola belanja konsumen dapat disebabkan oleh: 1). Kegunaan waktu (time ulility) maksudnya adalah kemampunaan perusahaan dalam menyediakan barang dan jasa yang dibutuhkan pada waktu yang tepat, 2). Kegunaan tempat (placa utility) yaitu kemampuaan perusahaan dalam menyediakan barang dan jasa yang dibutuhka di tempat yang terjangkau. 


\section{I.UMIRUNG}

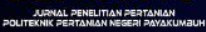

Pasar moderen ini merupakan mata rantai yang sangat penting dalam proses distribusi barang dan merupakan mata rantai terakhir dalam proses tersebut. Dalam ritel ini suatu produk dijual langsung kepada konsumen, sehingga dibutuhkan perhatian khusus untuk mendapatkan perhatian konsumen. Strategi umum yang digunakan dalam mendapatkan perhatian pelanggan dalam persaingan ritel moderen adalah penerapan strategi retail mix, ada 6 elemen dapat mempengaruhi konseumen yang terdiri dari: 1). costomers service, 2). store design and display, 3). communication mix, 4). location, 5). mechandise assorment dan 6). pricing (Levy \& Weitz, 2009). Sehingga setiap pasar moderen mempunyai kemampuan dan potensi tersendiri dalam mempengaruhi konsumen untuk berbelanja ditempat mereka.

Adapun rumusan masalah dalam penelitian ini adalah: 1).Apakah retail mix (customer service, store design \& display, communication mix, location, merchandise assortment, dan pricing) secara simultan berpengaruh terhadap keputusan berbelanja konsumen?, 2).Variabel manakan yang paling berpengaruh terhadap keputusan konsumen berbelanja di pasar moderen di Kota payakumbuh?

\section{METODE PENELITIAN}

\section{Waktu dan Tempat}

Penetian ini dimulai Juli 2019 sampai Desember 2019 lebih kurang selama 6 bulan. Tempat penelitan Kota Payakumbuh dengan objek penelitian pasar retail moderen di Kota Payakumbuh. Perkembangan pasar moderen seperti menimarket dan swalayan yang pesat di kota ini menjadi alasan peneliti untuk menentapkan Kota Payakumbuh menjadi daerah penelitian.

\section{Teknik Pengambilan Sampel}

Teknik pengambilan sampel yang akan digunakan adalah Insidental yaitu responden yang ditemuka secara tidak sengaja yang berada di objek penelitian (Suharyadi dan Purwanto, 2007). Jumlah sampel yang akan di gunakan dalam penelitilian ini menurut (Green, 1991) yaitu penelitian yang menggunakan analisis regresi berganda jumlah sampel yang dibutuhkan dapat menggunakan rumus 50+(8.n) dimana $\mathrm{n}$ adalah jumlah variabal yang akan digunakan dalam penelitian, sehinga jumlah sampel yang akan digunakan berdasarkan rumus diatas adalah $50+(8 \times 7)=106$ responden. 


\section{I.UMIPUNC}

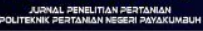

\section{Analisis Data}

Analisa data kualitatif adalah bentuk analisa yang berdasarkan dari data yang dinyatakan dalam bentuk uraian. Data kualitatif ini merupakan data yang hanya dapat diukur secara langsung, adapun proses yang dapat dilakukan seperti:

a. Pengeditan (editing)

Pengeditan adalah memilih atau mengambil data yang perlu dan membuang data yang dianggap tidak perlu, untuk memudahkan perhitungan dalam pengujian hipotesa.

b. Pemberian kode (coding)

Proses pemberian kode tertentu terhadap macam dari kuesioner untuk kelompok ke dalam kategori yang sama.

c. Pemberian skor ( scoring)

Mengubah data yang bersifat kualitatif kedalam bentuk kuantitatif. Dalam penelitian ini urutan pemberian skor menggunaka skal likert. Tingkatan skala likert yang digunakan dalam penelitian ini adalah sebagai berikut:

- Skor 5 untuk jawaban Sangat Setuju (SS)

- Skor 4 untuk jawaban Setuju (S)

- $\quad$ Skor 3 untuk jawaban netral (N)

- Skor 2 untuk jawaban Tidak Setuju (TS)

- Skor 1 untuk jawaban Sangat Tidak Setuju (STS)

d. Tabulasi (Tabulating)

Pengelompokan data atas jawaban dengan benar dan teliti, kemudian dihitung dan dijumlahkan sampai berwujud dalam bentuk yang berguna, berdasarkan hasil tabel tersebut akan disepakati untuk membuat data tabel agar mendapatkan hubungan atau pengaruh antara variabel-variabel yang ada.

\section{Analisis Kuantitatif}

Analisis data kuantitatif adalah bentuk analisa yang menggunakn angka-angka dan perhitungan dengan metode statistik, maka data tersebut harus diklasifikasikan dalam kategori tertentu dengan menggunakan tabel-tabel tertentu. Adapun alat analisis yang digunakan yaitu uji validitas dan realibilitas. 


\section{I.UMIBUNG}

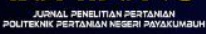

\section{Uji Validitas}

Uji validitas digunakan untuk mengukur sah atau valid tidaknya suatu kuesioner. Satu kuesioner dikatakan valid jika pertanyaan pada pertanyaan kuesioner mampu mengungkapkan sesuatu yang akan diukur oleh kuesioner tersebut (Ghozali, 2009).

Uji validitas ini dilakukan dengan cara melakukan korelasi antara skor masing-masing butir pertanyaan dengan total skor. Kuesioner dikatakan valid jika signifikan lebih kecil dari 0,05. Sebaliknya kuesioner dikatakan tidak valid jika signifikasi lebih besar dari 0,05.

\section{Uji Realibilitas}

Uji realibilitas digunakan untuk mengukur kuesioner yang merupakan indikator dari variabel. Kuesioner dikatakan reliable atau handal jika masing-masing pertanyaan dijawab responden secara konsisten atau stabil dari waktu ke waktu. Suatu kuesioner dikatakan handal jika nilai Cronbach Alpha lebih besar dari 0,600 (Ghozali, 2009).

\section{Uji Asumsi Klasik}

Untuk menguji apakah persamaan garis regresi yang diperoleh linier dan bisa dipergunakan untuk melakukan peramalan, maka harus dilakukan uji klasik yaitu:

\section{Uji Normalitas}

Uji normalitas bertujuan untuk mengetahui apakah dalam model regresi, variabel terikat dan variabel bebas memiliki distribusi yang normal atau mendekati normal. Pembuktian apakah data tersebut memiliki distribusi normal atau tidak dapat dilihat pada bentuk distribusi yang normal atau mendekati normal. Pembuktian apakah data tersebut memiliki distribusi normal atau tidak dapat dilihat pada bentuk distribusi datanya, yaitu pada histogram maupun normal probability plot. Pada histogram, data dikatakan memiliki distribusi yang normal jika data tersebut berbentuk seperti lonceng. Sedangkan pada normal probability plot, dapat dikatakan normal jika ada penyebaran titik-titik disekitar garis diagonal dan penyebarannya mengikuti arah diagonal. Ghozali (2009) menyebutkan jika data menyebar disekitar garis diagonal dan mengikuti arah garis diagonal maka model regresi memenuhi asumsi normalitas.

\section{Uji Multikolinearitas}

Multikolinearitas merupakan hubungan linier yang sempurna antara beberapa atau semua variabel bebas. Pengujian multikolinearitas bertujuan untuk mengetahui apakah dalam model regresi ditemukan adanya korelasi antar variabel. 


\section{I.UMIBUNG}

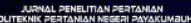

Multikolinearitas dapat dideteksi dengan menganalisis matrik korelasi variabelvariabel independen atau dengan menggunakan perhitungan nilai Tolerance kurang dari 0,100 atau nilai VIP lebih dari 10, maka hal ini menunjukkan adanya multikolinearitas (Ghozali, 2009).

\section{Uji Heteroskedastisitas}

Tujuan pengujian ini adalah untuk mengetahui apakah dalam model regresi terjadi ketidaksamaan variance dari residual satu pengamatan ke pengamatan yang lain. Jika variance dari residual satu pengamatan ke pengamatan lain tetap maka disebut homokedastisitas, namun jika berbeda disebut heterokedastisitas. Model regresi yang baik adalah homokedastisitas atau tidak terjadi heterokedastisitas.

Salah satu cara untuk mendeteksi ada atau tidaknya heterokedastisitas adalah dengan melihat grafik plot antara prediksi variabel dependen (SRESIDE) dengan residualnya (ZPRED). Deteksi ada tidaknya heterokedastisitas dapat dilakukan dengan melihat ada tidaknya pola titik pada garis scatterplot antara SRESIDE dan ZPRED, dimana sumbu Y adalah $\mathrm{Y}$ yang telah diprediksi dan sumbu $\mathrm{X}$ adalah residual yang telah di-standarized (Ghozali, 2009). Jika ada pola tertentu, seperti titik-titik yang ada membentuk suatu pola yang teratur (bergelombang melebar kemudian menyempit) maka terjadi heteroskedastisitas. Dan jika tidak ada pola yang jelas seperti titik-titik menyebar diatas dan dibawah angka 0 pada sumbu Y, maka hal inimengindikasikan tidak terjadi heterokedastisitas.

\section{Persamaan Regresi Linear Berganda}

Adapun bentuk persamaan regresi berganda yang digunakan dalam penelitian ini sebagi berikut:

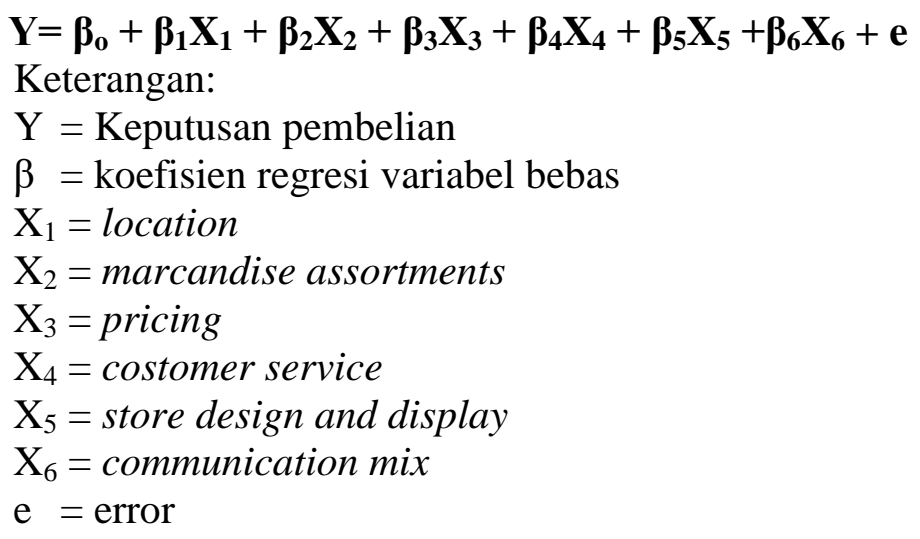




\section{I.UMIBUNG}

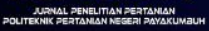

\section{Uji Kelayakan Model}

Uji ini dilakukan untuk melihat apakah model yang dianalisis memiliki tingkat kelayakan model yang tinggi yaitu variabel-variabel yang digunakan mampu untuk menjelaskan fenomena yang dianalisis. Dua indikator yang digunakan untuk menguji kelayakan model adalah:

1. Uji Anova (Uji F)

Uji $F$ bertujuan untuk menunjukkan apakah semua variabel independen yang dimasukkaan ke dalam model secara stimultan atau bersama-sama mempunyai pengaruh terhadap variabel dependen (Ghozali, 2009).

Membuat hipotesis untuk kasus pengujian F-test diatas, yaitu:

Ho: $\mathrm{b} 1=\mathrm{b} 2=\mathrm{b} 3=0$

Artinya: tidak ada pengaruh yang signifikan dari variabel independen yaitu location $\left(X_{1}\right)$, marcandise assortments $\left(X_{2}\right)$, pricing $\left(X_{3}\right)$, costomer ervice $\left(X_{4}\right)$, store design and display $\left(X_{5}\right)$, dan communication mix $\left(X_{6}\right)$ secara simultan terhadap variabel dependen yaitu keputusan pembelian (Y).

Ha : b1, b2, b3>0

Artinya: ada pengaruh yang signifikan dari variabel independen yaitulocation $\left(X_{1}\right)$, marcandise assortments $\left(X_{2}\right)$, pricing $\left(X_{3}\right)$, costomer ervice $\left(X_{4}\right)$, store design and display $\left(X_{5}\right)$, dan communication mix $\left(X_{6}\right)$ secara simultan terhadap variabel dependen yaitu keputusan pembelian (Y).

Menentukan F table dan F hitung dengan tingkat kepercayaan sebesar 95\% atau taraf signifikansi sebesar 5\%, maka:

- Jika F Hitung > F Tabel, maka Ho ditolak, berarti masing-masing variabel bebas secara bersama-sama mempunyai pengaruh yang signifikan terhadap variabel terikat.

- Jika F Hitung < F Tabel, maka Ho diterima, berarti masing-masing variabel bebas secara bersama-sama tidak mempunyai pengaruh yang signifikan terhadap variabel terikat.

2. Koefisien Determinasi (adjusted $\mathrm{R}^{2}$ )

Koefisien determinasi bertujuan untuk mengukur seberapa jauh kemampuan model dalam menerangkan variasi dependen. Nilai koefisien determinasi adalah $0<\mathrm{R}^{2}<1$. Koefisien determinasi yang mendekati satu berarti variabel-variabel independen memberikan hampir semua informasi yang dibutuhkan untuk memprediksi variabel dependen, penggunaan 


\section{I.UMIBUNG}

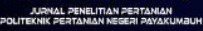

R Square adalah bias terhadap jumlah variabel independen yang dimasukkan ke dalam model, setiap tambahan variabel independen ke dalam model, maka $\mathrm{R}$ square pasti meningkat tidak peduli apakah variabel independen tersebut berpengaruh secara signifikan atau tidak. Tidak seperti $\mathrm{R}$ Square, nilai adjusted $\mathrm{R}$ square dapat naik atau turun apabila terdapat tambahan variabel independen kedalam model. Oleh karena itu sebaiknya digunakan nilai adjusted R Square untuk mengevaluasi model regresi terbaik (Ghozali, 2009).

3. Uji Hipotesis

Uji t digunakan untuk menunjukkan apakah suatu variabel independen secara individual mempengaruhi variabel dependen (Ghozali, 2009)

Hipotesis yang dipakai adalah:

Ho: b1=0, artinya suatu variabel independen tidak berpengaruh terhadap variabel dependen.

Ha: b1>0, artinya suatu variabel independen berpengaruh positif terhadap variabel dependen

Kriteria pengujian dengan tingkat signifikasi $95 \%$ ditentukan sebagai berikut:

Apabila t hitung >t table, maka Ho ditolak dan Ha diterima

Apabila t hitung < t table, maka H0 diterima dan Ha ditolak.

\section{HASIL DAN PEMBAHASAN}

\section{Uji Instrumen Penelitian}

\section{Uji Validitas}

Uji Validitas adalah suatu ukuran yang menunnjukan kesahihan isntrumen peneltian dalam mengukur apa yang ingin di ukur oleh si peneliti. Validitas tersebut berasal dari kata validity yang menpunyai arti sejauh mana ketepatan kecermatan suatu alat ukur dalam melakukan fungsi ukutnya.

Uji validitas dalam penelitian ini menggunakan korelasi Bivariate Pearson (Produk Momen Pearson) yang mana analisis ini mengkorelasikan masing-masing skor item dengan skor totalnya. Jika r-hitung >r-tabel maka instrumen penelitian berkorelasi signifikasn terhadap skor total maka dinyatakan valid.

Uji validitas dengan SPSS 20 adalah: analyze => correlate => bivariate => "Pearson" dan "two-tailed". Kemudian akan keluar nilai r-hitung, kemudia dibandingkan dengan rtabel dapat dilihat pada tabel $\mathrm{r}$ statistik, dimana nilai $\mathrm{df}=\mathrm{N}-2$, disini jumlah responden yang 


\section{I.UMIBUNG}

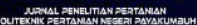

digunakan adalah $\mathrm{N}=30$ dan jika mengikuti rumus maka $\mathrm{df}=\mathrm{N}(30)-2=28$ jadi kita melihat nilai df $16=0,3610$.

Tabel 1. Uji validasi dan realibilitas

\begin{tabular}{|c|c|c|c|c|}
\hline \multirow[b]{2}{*}{ Indikator } & \multicolumn{2}{|c|}{ Korelasi (r) } & \multicolumn{2}{|c|}{ Koefisien } \\
\hline & $\mathbf{R}$ & Status & $\begin{array}{l}\text { Alpha } \\
\text { cronbach's }\end{array}$ & Status \\
\hline \multicolumn{5}{|c|}{ Location $\left(X_{1}\right)$} \\
\hline Lokasi mudah di jangkau trategis & 0,404 & Valid & \multirow{5}{*}{0.756} & Reliabel \\
\hline Lokasi di perumahan padat penduduk & 0,337 & $\begin{array}{l}\text { Tidak } \\
\text { Valid }\end{array}$ & & \\
\hline Lokasi di lalui trasnportasi umum & 0,420 & Valid & & Reliabel \\
\hline $\begin{array}{l}\text { Lokasi minimarket menyediakan tempat parkir } \\
\text { yang layak }\end{array}$ & 0,559 & Valid & & Reliabel \\
\hline $\begin{array}{l}\text { Lokasi minimarket menyediakan tempat yang aman } \\
\text { bagi kendaraan pribadi }\end{array}$ & 0,689 & Valid & & Reliabel \\
\hline \multicolumn{5}{|c|}{ Marcandise assortments $\left(\mathrm{X}_{2}\right)$} \\
\hline Produk yang di sedikan lengkap & 0,833 & Valid & \multirow{3}{*}{0,761} & Reliabel \\
\hline $\begin{array}{l}\text { Minimarket menyediakan pilihan merek produk } \\
\text { dengan keguaan yang sam }\end{array}$ & 0,776 & Valid & & Reliabel \\
\hline $\begin{array}{l}\text { Mutu produk yang disediakan mutunya terjamin } \\
\text { (tidak kadarluarsa) }\end{array}$ & 0,720 & Valid & & Reliabel \\
\hline \multicolumn{5}{|c|}{ Pricing $\left(X_{3}\right)$} \\
\hline $\begin{array}{l}\text { Minimarket menawarkan harga yang kompetetitif } \\
\text { dibanding pesaing }\end{array}$ & 0,729 & Valid & \multirow{5}{*}{0,816} & Reliabel \\
\hline $\begin{array}{l}\text { Minimarket menawarkan produk yang sesuai } \\
\text { dengan kualitas produk }\end{array}$ & 0,743 & Valid & & Reliabel \\
\hline $\begin{array}{l}\text { Minimarket menawarkan pemotongan harga pada } \\
\text { saat-saat tertentu }\end{array}$ & 0,654 & Valid & & Reliabel \\
\hline $\begin{array}{l}\text { Minimarket menawarkan kemudahan dalam } \\
\text { membayar tunai atau debit kartu kredit }\end{array}$ & 0,464 & Valid & & Reliabel \\
\hline \multicolumn{4}{|c|}{ Costomer service $\left(\mathrm{X}_{4}\right)$} & \\
\hline Pramuniaga cekatan dalam melayani konsumen & 0,698 & Valid & \multirow{4}{*}{0,904} & Reliabel \\
\hline $\begin{array}{l}\text { Pramuniaga cepat tanggap terhadap pertanyaan } \\
\text { konsumen }\end{array}$ & 0,807 & Valid & & Reliabel \\
\hline $\begin{array}{l}\text { Pramuniaga mampu menjelasakan informasi } \\
\text { produk yang ingin di ketahui konsumen }\end{array}$ & 0,711 & Valid & & Reliabel \\
\hline Pramuniaga ramah dalam melayani konsumen & 0,672 & Valid & & Reliabel \\
\hline \multicolumn{5}{|c|}{ Store design and display $\left(\mathrm{X}_{5}\right)$} \\
\hline Pencahayaan didalam toko sangat terang & 0,661 & Valid & \multirow{4}{*}{0,81} & Reliabel \\
\hline $\begin{array}{l}\text { Lantunan musik didalam toko membuat nyaman } \\
\text { dalam berbelanja }\end{array}$ & 0,613 & Valid & & Reliabel \\
\hline $\begin{array}{l}\text { Penyusunan rak didalam toko sangat rapi dan } \\
\text { mudah dijangkau }\end{array}$ & 0,800 & Valid & & Reliabel \\
\hline $\begin{array}{l}\text { Barang yang ditawarkan akurat sesui dengan } \\
\text { spesifikasi/janjikan }\end{array}$ & 0,824 & Valid & & Reliabel \\
\hline \multicolumn{5}{|c|}{ Communication mix $\left(\mathrm{X}_{6}\right)$} \\
\hline $\begin{array}{l}\text { Minimarket selalu menawarkan harga menarik dan } \\
\text { potongan harga pada produk tertentu }\end{array}$ & 0,757 & Valid & \multirow{3}{*}{0,720} & Reliabel \\
\hline $\begin{array}{l}\text { Saya mengetahui promo di minimarket melalui } \\
\text { iklan di media masa/baliho/media social }\end{array}$ & 0,539 & Valid & & Reliabel \\
\hline Papan nama/neon box minimarket terlihat jelas dari & 0,746 & Valid & & Reliabel \\
\hline
\end{tabular}




\section{I.UMIBUNG}

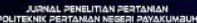

depan

Keputusan Pembelian (Y)

Minimarket mampu menyediakan produk

$0,744 \quad$ Valid

Reliabel

kebutuhan konsumen dengan cepat

Minimarket mengerti kebutuhan konsumen

Anda memiliki keinginan untuk melakukan

$0,778 \quad$ Valid

Reliabel

pembelian ulang di minimarket

Anda melakukan pembelian dari lini produk lain di

$0,769 \quad$ Valid

Reliabel

minimarket

Anda merekomendasikan minimarket sebagai

tempat berbelanja kepada orang terdekat anda

Anda memiliki komitmen untuk menjadi pelanggan

minimarket dalam jangka panjang

Anda memiliki komitmen untuk menjadi pelanggan

minimarket dalam jangka panjang

$\begin{array}{cccc}0,493 & \text { Valid } & & \text { Reliabel } \\ 0,645 & \text { Valid } & 0,877 & \text { Reliabel } \\ 0,702 & \text { Valid } & & \text { Reliabel } \\ 0,439 & \text { Valid } & \text { Reliabel }\end{array}$

Dari hasil uji valid, hanya item LKS-2 pada variabel $\mathrm{X}_{1}$ yang tidak valid, karena nilani r hitung $(0,337)$ masih lebih kecil dari nilai $r$ tabel 0,361 , sebelum dilanjutkan uji reabilitas maka item ini akan dikeluarkan dari kuesioner untuk mendapatkan data yang lebih baik, sedangkan sisanya valid.

Uji Realibilitas dapat kita artikan secara umum bahwa kuesioner yang digunakan dalam penelitian tersebut konsisten walaupun digunakan ditempat lain dengan indikator yang sama. Tingkat konsistensi pada alat ukur sangat diperlukan dalam penelitian karena dengan gejala yang sama maka alat ukut penelitian tersebut dapat digunakan untuk menyimpulkan suatu dimanamika yang terjadi tersebut.

Penelitian ini menggunakan SPSS dengan pendekatan Alpa Cronbach karena instrumen peneltian ini berbentuk skla bertingkat. Uji Realibilitas dapat dilakuan secara bersama-sama terhadap seluruh item pertanyaan dengan dasar pengambilan keputusannya adalah sebagai berikut:

Jika nilai Cronbach's Alpha > 0,60 maka kuesioner dinyatakan reliabel atau konsisten. Jika nilai Cronbach's Alpha $<0,60$ maka kuesioner dinyatakan tidak reliabel atau tidak konsisten.

Uji Realibilitas pada SPSS klik Analyze -> Scala -> Reliability Analysis -> (masukan semua item) -> model Alpha -> klik OK. Dari hasil uji reliabilitas, yang dilihat adalah nilai cronbach's alpha nilai cronbach's alpha yang kita peroleh besar dari masing-masing variabel yaitu $\geq 0,60$. 


\section{I.UMIBUNG}

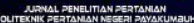

\section{Karakteristik Responden}

Responden terdiri dari pelanggan minimarket yang ada di Kota Payakumbuh dengan jumlah 118 responden, responden juga lima kecamatan yang ada di Kota Payakumbuh seperti pada grafik dibawah ini:

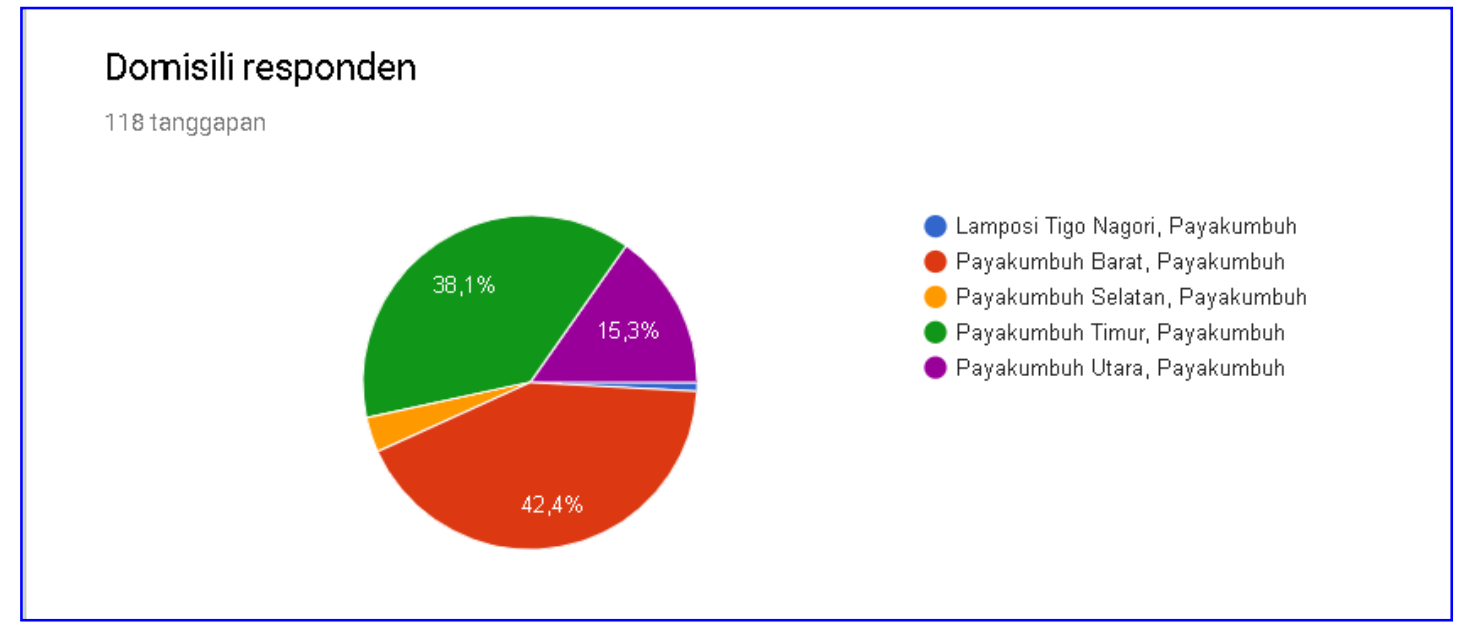

Gambar 1. Persentase responden berdasarkan domisili kecamatan

\section{Uji Asumsi Klasik}

\section{Uji Normalitas}

Uji normalitas menggunakan grafik histogram dan QQ flot seperti grafik dibawah ini:

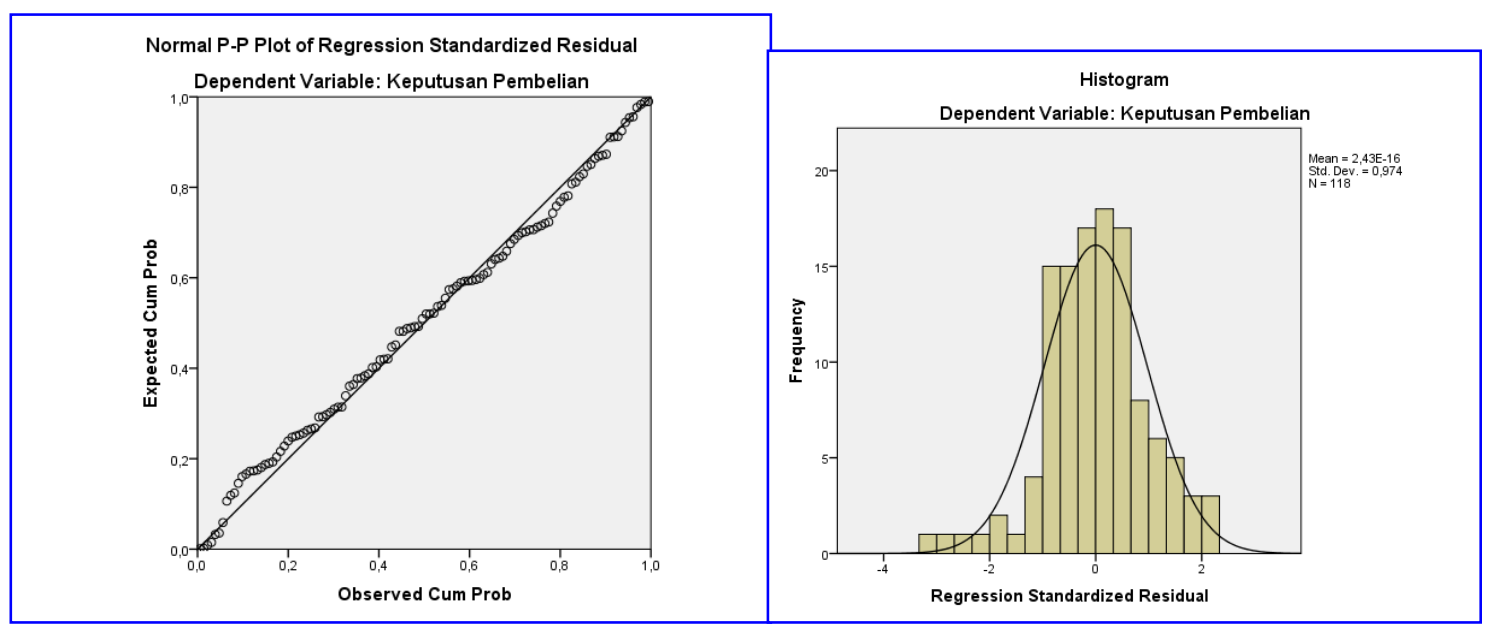

Gambar 2. Uji Normalitas

Dari grafik diatas menunjukkan bahwa plot-plot mengikuti garis fit line maka variable berdistribusi normal, begitu juga pada grafik histogram sebagian besar bar mengikuti garis lengkung maka dapat dikatakan bahwa variabel berdistribusi normal. 


\section{I.UMIBUNG}

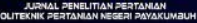

\section{Uji Heteroskedastisitas}

Metode yang digunakan intuk menguji heteroskedastisitas dalam penelitian ini adalah analisis grafik dilakukan dengan mergresikan semua variabel bebas terhadap nilai mutlak residualnya. Berikut ini merupakan scatterplot dari hasil pengujian:

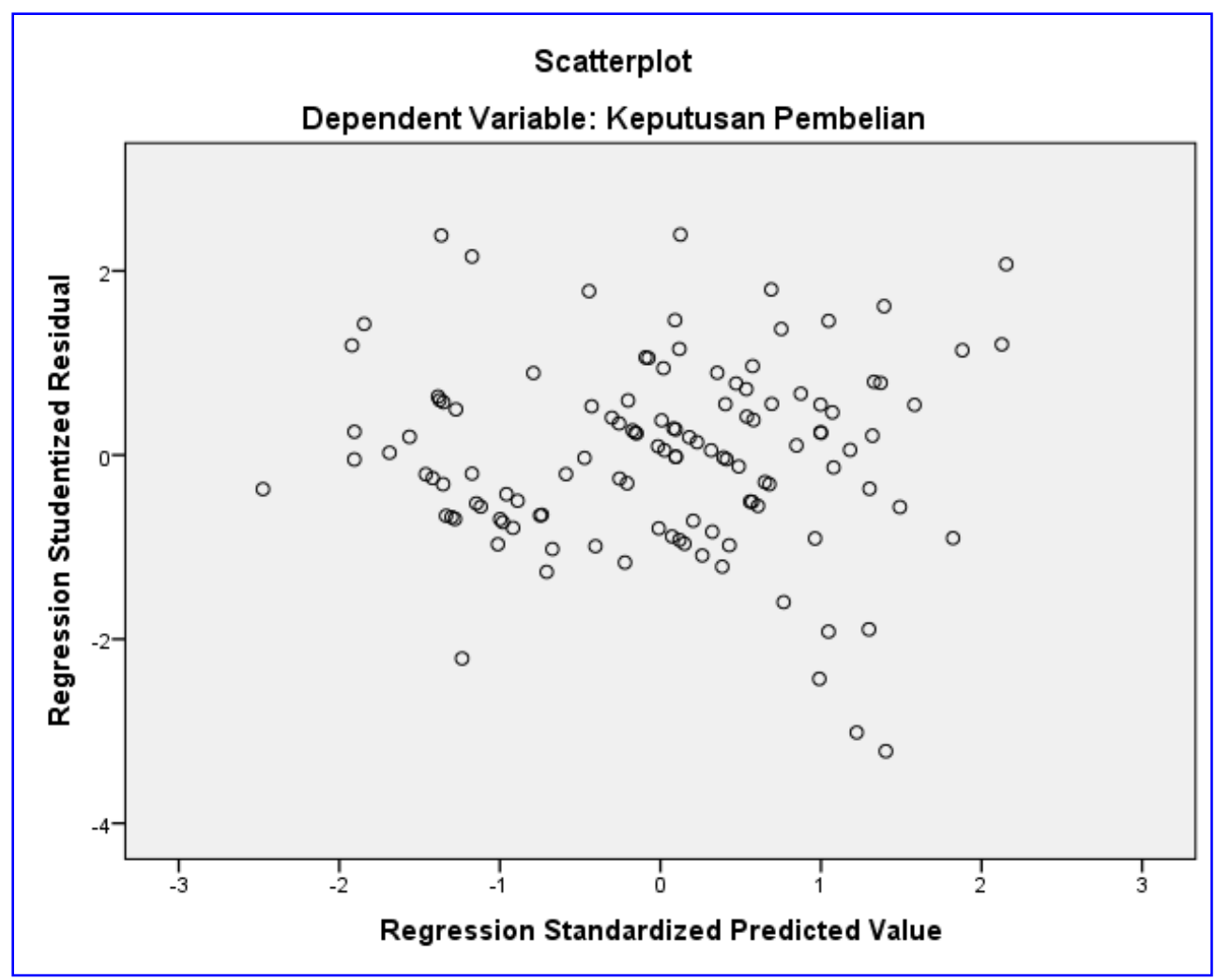

Gambar 3. Scatterplot uji heteroskedastisitas

Berdasarkan tampilan pada scatterplot terlihat bahwa plot menyebar secara acak diatas maupun dibawah angka nol sumbu regression studentized residual. Oleh karena itu berdasarkan uji heterosedastisitas menggunakan metode analisis grafik dapat dinyatakan tidak terjadi heteroskedastisitas.

\section{Multikolinearitas}

Uji multikolinieritas dilakukan untuk menguji apakah pada model regresi ditemukan adanya korelasi antar variabel independent. Jika dalam model regresi yang terbentuk terdapat korelasi yang tinggi atau sempurna antara variabel bebas maka model tersebut dinyatakan mengandung gejala multikolinieritas. Untuk menguji ada atau tidaknya gejala multikolinieritas dapat dilakukan dengan melihat collinerity statistic dari nilai VIF yang tidak melebihi 10. Berikut adalah hasil output yang diperoleh untuk pengujian multikolinieritas. 


\section{I.UMIAUNC}

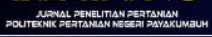

Tabel 2. Uji Multikolinearitas

\begin{tabular}{lrr}
\hline \multicolumn{1}{c}{ Variabel } & Tolerance & VIF \\
\hline Location $(X 1)$ & 0,788 & 1,269 \\
Marcandise assortments $(X 2)$ & 0,591 & 1,692 \\
Pricing $(X 3)$ & 0,896 & 1,117 \\
Costomer service (X4) & 0,703 & 1,423 \\
Store design and display (X5) & 0,793 & 1,261 \\
Communication mix (X6) & 0,541 & 1,847 \\
\hline
\end{tabular}

Berdasarkan output terlihat bahwa nilai nilai VIF untuk semua variabel < dari 10.

Dengan demikian dapat disimpulkan bahwa dalam model regresi tidak terdapat gejala multikolinieritas.

Tabel 3. Model Summary output SPSS

Model Summary

\begin{tabular}{|l|c|r|r|r|}
\hline Model & R & R Square & $\begin{array}{c}\text { Adjusted R } \\
\text { Square }\end{array}$ & $\begin{array}{c}\text { Std. Error of } \\
\text { the Estimate }\end{array}$ \\
\hline 1 &, $717^{\text {a }}$ &, 514 &, 488 & 3,44334 \\
\hline
\end{tabular}

a. Predictors: (Constant), Communication mix, Pricing, Store design and display, Location, Costomer service, Marcandise assortments

b. Dependent Variable: Keputusan Pembelian

$\mathrm{R}^{2}$ sebesar 0,514 menunjukkan uji ketepatan perkiraan (goodness of fit) dari model persamaaan adalah baik. Hal ini berarti bahwa 51,4\% keragaman variabel terikat yaitu keputusan konsumen berbelanaja diminimarket dapat dijelasakan oleh keragamanan variabelvariabel bebas yaitu location, Marcandise assortments, Pricing, Costomer servic, Store design and display, dan Communication mix, sedangkan sisanya 49,6\% dijelaskan oleh variabel lin diluar model.

Sementara itu nilai korelasi (R) yang diperoleh adalah sebsar 0.717 ini menunjukkan bahwa faktor location, Marcandise assortments, Pricing, Costomer servic, Store design and display, dan Communication mix memiliki pengaruh yang cukup kuat terhadap keputusan belanja di minimarket.

Tabel 4. Uji F

ANOVAa

\begin{tabular}{|c|c|c|c|c|c|c|}
\hline & & $\begin{array}{c}\text { Sum of } \\
\text { Squares }\end{array}$ & df & Mean Square & $F$ & Sig. \\
\hline \multirow[t]{3}{*}{1} & Regression & 1392,773 & 6 & 232,129 & 19,578 & $.000^{6}$ \\
\hline & Residual & 1316,083 & 111 & 11,857 & & \\
\hline & Total & 2708,856 & 117 & & & \\
\hline
\end{tabular}

a. Dependent Variable: Keputusan Pembelian

b. Predictors: (Constant), Communication mix, Pricing, Store design and display, Location, Costomer service, Marcandise assortments 


\section{I.UMIBUNG}

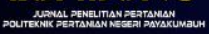

Uji F pada tabel ANOVA menunjukkan hasil yang baik. Hal ini dapat dilihat dari angka probabilitas F statistic sebesar 19,578 dengan signifikansi sebesar 0.000 yang nilainya lebih kecil dari 0.05 , berarti bahwa minimum ada satu variabel bebas berpengaruh signifikan terhadap variabel terikat.

\section{Analisis regresi linier berganda}

Perhitungan analisis regrsisi berganda menggunakan program SPSS dengan variabel independen: location $\left(X_{1}\right)$, Marcandise assortments $\left(X_{2}\right)$, Pricing $\left(X_{3}\right)$, Costomer servic $\left(X_{4}\right)$, Store design and display $\left(X_{5}\right)$, dan Communication mix $\left(X_{6}\right)$ serta variabel dependen keputusan pembelian (Y) sebagai berikut:

Tabel 5. Uji T dan Koefisien Regesi

\begin{tabular}{|c|c|c|c|c|c|c|c|c|}
\hline \multicolumn{9}{|c|}{ Coefficients $^{a}$} \\
\hline & & \multicolumn{2}{|c|}{ Unstandardized Coefficients } & \multirow{2}{*}{$\begin{array}{c}\text { Standardized } \\
\text { Coefficients } \\
\text { Beta }\end{array}$} & \multirow[b]{2}{*}{$t$} & \multirow[b]{2}{*}{ Sig. } & \multicolumn{2}{|c|}{ Collinearity Statistics } \\
\hline \multicolumn{2}{|c|}{ Model } & $B$ & Std. Error & & & & Tolerance & VIF \\
\hline \multirow[t]{7}{*}{1} & (Constant) & 2,267 & 3,660 & &, 619 & .537 & & \\
\hline & Location & 115 &, 080 &, 108 & 1,448 &, 150 & ,788 & 1,269 \\
\hline & Marcandise assortments &, 118 & 082 &, 124 & 1,441 &, 152 &, 591 & 1,692 \\
\hline & Pricing &, 004 &, 024 &, 013 &, 183 & 855 &, 896 & 1,117 \\
\hline & Costomer service &,- 035 &, 065 &,- 042 &,- 537 &, 592 & ,703 & 1,423 \\
\hline & Store design and display &, 365 &, 070 &, 387 & 5,207 &, 000 & ,793 & 1,261 \\
\hline & Communication mix &, 325 &, 084 &, 348 & 3,872 &, 000 &, 541 & 1,847 \\
\hline
\end{tabular}

a. Dependent Variable: Keputusan Pembelian

A. Nilai konstanta 2,267 artinya jika variabel independen yang terdiri dari location $\left(X_{1}\right)$, Marcandise assortments $\left(X_{2}\right)$, Pricing $\left(X_{3}\right), \quad$ Costomer servic $\left(X_{4}\right)$, Store design and display $\left(X_{5}\right)$, communication mix $\left(X_{6}\right)$ dianggap 0 (nol) atau tidak diterapkan maka keputusan pembelian pada minimarket dikota payakumbuh sebesar 2,267 satuan.

B. Koefisien regresi location $\left(\mathrm{X}_{1}\right)$ sebesar 0,115 , artinya lokasi meningkat atau menjadi lebih strategis sebesar 1 skala dalam jawaban responden, maka akan meingkat keputusan pembelian pada minimarket di Kota Payakumbuh sebesar 0,115 satuan dengan asusmsi veriabel lain dianggap tetap.

C. Koefisien regresi Marcandise assortments $\left(X_{2}\right)$ sebesar 0,118 artinya, jika Marcandise assortments /produk nilainya naik 1 skala dalam jawaban responden maka akan meningkat keputusan pembelian sebesar 0,118 pada minimarket yang ada di Kota Payakumbuh dengan asusmsi variabl lain tetap.

D. Koefisien regresi Pricing $\left(X_{3}\right)$ sebesar 0,004, artinya jika harga meningkat 1 skala pada jawaban responden maka akan meningkat keputusan pembeliaan sebesar 0,004 satuan di minimarket di Kota Payakumbuh dengan asumsi variabel lain tetap. 


\section{I.UMIBUNG}

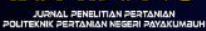

E. Koefisien regresi Costomer servic $\left(X_{4}\right)$ sebesar -0,035, artinya jika pelayanan meningkat 1 skala dalam jawaban responden, maka menurunkan keputusan pembelian sebesar 0,035 satuan dengan asusmsi variabel lain tetap.

F. Koefisien regresi Store design and display $\left(X_{5}\right)$ sebesar 0,365 , artinya jika disain toko dan tampilan meningkat 1 skala dalam jawaban responde makameningkatkan keputusan pembelian sebesar 0,365 satuan dengan asumsi variabel lain tetap.

G. Koefisien regresi communication mix $\left(X_{6}\right)$ sebesar 0,325 , artinya jika cummunication mix naik 1 skala dalam jawaban responden, maka akan meningkat keputusan pembelian di minimarket di Kota Payakumbuh sebesar 0,325 dengan asumsi variabel lain tetap.

\section{Uji Hipotesis Secara Parsial (Uji t)}

Uji hipotesis secara parsial pada coefisien hasil output SPSS untuk melihat ada atau tidaknya pengaruh variabel independen terhadap variabel dependen, untuk menentukan tingkat signifikan suatu varibel dapat meilhat nilai signifikan pada hasi output SPSS atau dengan cara membandingkan nilai T-hit dengan T-tabel. Nilai t-hitung sudah ada pada outpus SPSS dedangkan nilai t-tabel dicari dengan rumus $\mathrm{df}=\mathrm{n}-\mathrm{k}$ yaitu $\mathrm{df}=118-7=111$ dengan probalitasnya $0,05 / 2=0,025$, maka hasil nilai t-tabel yang didapatkan adalah 2,272, maka uji hipotesisnya sebagai berikut:

1. Nilai $t_{\text {hitung }}$ untuk variabel location $\left(X_{1}\right)$ sebesar 1,448 lebih kecil dari nilai $t_{\text {tabel }} 2,272$, dengan tingkat signifikan $0,150>0,05$, artinya $\mathrm{H}_{0}$ diterima dan $\mathrm{H}_{1}$ ditolak, maka location tidak berpengaruh signifikan terhadap keputusan pembelian konsumen pada minimarket di Kota Payakumbuh.

2. Nilai $t_{\text {hitung }}$ untuk variabel Marcandise assortments $\left(X_{2}\right)$ sebesar 1,441 lebih kecil dari nilai $t_{\text {tabel }} 2,272$, dengan tingkat signifikan $0,152>0,05$, artinya $\mathrm{H}_{0}$ diterima dan $\mathrm{H}_{1}$ ditolak, maka Marcandise assortments tidak berpengaruh signifikan terhadap keputusan pembelian konsumen pada minimarket di Kota Payakumbuh.

3. Nilai $t_{\text {hitung }}$ untuk variabel Pricing $\left(X_{3}\right)$ sebesar 0,183 lebih kecil dari nilai $t_{\text {tabel }} 2,272$, dengan tingkat signifikan 0,855 > 0,05, artinya $\mathrm{H}_{0}$ diterima dan $\mathrm{H}_{1}$ ditolak, maka Pricing $\left(X_{3}\right)$ tidak berpengaruh signifikan terhadap keputusan pembelian konsumen pada minimarket di Kota Payakumbuh.

4. Nilai $t_{\text {hitung }}$ untuk variabel Costomer servic $\left(X_{4}\right)$ sebesar $-0,537$ lebih kecil dari nilai $t_{\text {tabel }}$ 2,272, dengan tingkat signifikan $0,592>0,05$, artinya $\mathrm{H}_{0}$ diterima dan $\mathrm{H}_{1}$ ditolak, 


\section{I.UMIBUNG}

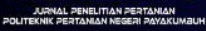

makaCostomer servic $\left(X_{4}\right)$ tidak berpengaruh signifikan terhadap keputusan pembelian konsumen pada minimarket di Kota Payakumbuh.

5. Nilai $t_{\text {hitung }}$ untuk variabel Store design and display $\left(X_{5}\right)$ sebesar 5,207 lebih besar dari nilai $t_{\text {tabel }} 2,272$, dengan tingkat signifikan $0,000<0,05$, artinya $\mathrm{H}_{0}$ ditolaka dan $\mathrm{H}_{1}$ diterima, maka Store design and display $\left(X_{5}\right)$ berpengaruh signifikan terhadap keputusan pembelian konsumen pada minimarket di Kota Payakumbuh.

6. Nilai $t_{\text {hitung }}$ untuk variabel communication mix $\left(X_{6}\right)$ sebesar 3,872 lebih besar dari nilai $t_{\text {tabel }}$ 2,272, dengan tingkat signifikan $0,000<0,05$, artinya $\mathrm{H}_{0}$ ditolak dan $\mathrm{H}_{1}$ diterima, maka communication mix $\left(X_{6}\right)$ berpengaruh signifikan terhadap keputusan pembelian konsumen pada minimarket di Kota Payakumbuh.

Perkembangan minimarket di Kota Payakumbuh mengikuti tren yang ada yaitu di lokasi strategis di jalan utama seperti tabel dibawah ini:

Tabel 6. Lokasi minimarket di Kota Payakumbuh

\begin{tabular}{ll}
\hline \multicolumn{1}{c}{ Jalan Uatama } & \multicolumn{1}{c}{ Minimarket/Swalayan } \\
\hline Jalan A. Yani & Nabuma Swalayan, Raja mart 2, Nela dan Cake Mart \\
Jalan Sukarno-Hatta & Ramayana Swalayan, Mega Prima, Raja Mart 1, Niagara \\
& Swalayan, Budiman Swalayan, RJ Mart \\
Jalan Tan Malaka & CO-OP Mart, Karya Putra \\
Jalan Sudirman & Tara Mart \\
Jalan Ade Irma Suryani & SM Mart \\
Jalan Rasuna Said & Dede Setia Mart \\
\hline
\end{tabular}

Berdasarkan hasil analsis statistik didapatkan lokasi tidak berpengaruh nyata terhadap keputusan pembelian konsumen diminimarket di Kota Payakumbuh disebabkan perkembangan minimarket semuanya sangat strategis dan lokasi yang semuanya dijalan utama.

Produk-produk yang dijual di minimarket Kota Payakumbuh sebagian besar berasal dari distributor yang sama dari hasil observasi peneliti bahwa agen-agen yang datang untuk menawarkan produk dari Kota Padang dan Kota Bukitinggi dan ada juga yang dari Kota Payakumbuh, ini berdampak kepada produk-produk atau Marcandise assortments hapir serupa dan berdapak juga terhadap harga dasar yang sama, maka konsumen sangat susah membedakan antara minimaket untuk membeli produk dengan tingkat harga yang lebih murah maka Marcandise assortments $\left(X_{2}\right)$ dan Price $\left(X_{3}\right)$ tidak berpengaruh nyata terhadap keputusan konsumen dalam bebelanja di minimarket di Kota Payakumbuh. 


\section{I.UMIBUNG}

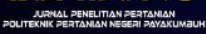

Sedangkan untuk pelayanan / Costomer servic $\left(X_{4}\right)$ tidak berpengaruhnya terhadap peputusan pembelian karena prisip orang berbelaja keminimarket salah satunya bebas memilih dan menentukan harga mana yang lebih di sukai, jika terlalu banyak campur tangan pelayanan dalam minimarket membuat konsumen terganggu maka dalam penelitian ini responden pelayanan berslop negatif yang artinya semakin ditingkat pelayanan dan tidak dibeli kebebasan pada konsumen maka akan semakin menurun minat konsumen berbelaja ke minimarket.

Kemudian variabel Store design and display $\left(X_{5}\right)$ berpengaruh nyata terhadap keputusan pembelian konsumen keminimarket di Kota payakumbuh, susunan produk di minimarket yang rapi dan tampilan minimarkat yang elegan dan memberikan nuansa kenyamanan membuat daya tarik konsumen untuk berbelanja di minimarket, hal ini sesuai dengan rekomendasi responden dalam memilih minimarket sebagai berikut:

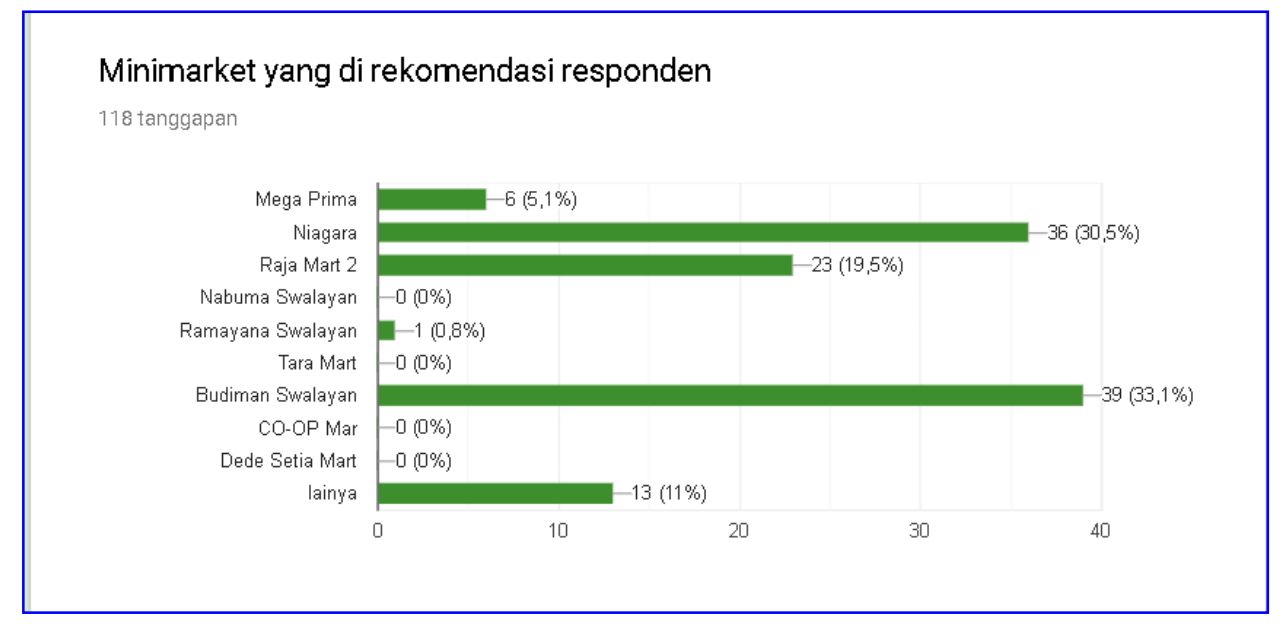

Gambar 4. Minimarket yang rekomendasi konsumen

Dari tabel diatas terlihat rekomendasi 118 responden adalah di Budiman Swalayan 33,1\%, kemudian di Niagara 30,3\%, raja mart 2 sebesar 19,5\% dan nela cake and mart (11\%), dari observasi peneliti bahwa minimarket Budiman Swalayan baru tahun 2019 beroperasi di Kota Payakumbuh dengan berpengalaman yang panjang karena merupakan cabang dari Budiman Swalayan di Kota Bukitinggi yang juga sudah memiliki beberapa jabang di kota-kota yang ada di Propinsi Sumatera Barat, minimarket ini mempunyai produkproduk terlengkap dengan susunan produk yang paling rapi dan menerapkan kenyamanan berbelanja konsumen, hal ini tidak terlepas dari pengalaman owner dari kedua minimarket tersebut.

Kemudian variabel communication mix berpengaruh nyata terhadap keputusan pembelian konsumen di minimarket, hal ini sangat terlihat dari nela cake and mart yang baru 


\section{I.UMIRUNG}

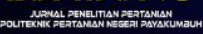

beroperasi 2019 akan tetapi dengan tampilan minimarket yang comunikatif, warna menarik, mewah yang jelas tampilan berbeda dari minimarket yang sudah ada, sehingga beru beroperasi tahun 2019 sudah menjadi minimarket rekomendasi ke 4 dari dari penelitian ini.

\section{KESIMPULAN}

Koefiesien determinasi (R2) pada penelitian ini adalah 0,514 yang artinya bahwa variabel bebas yang dimasukan dalam penelitian sudah mampu menjelaskan 51,4\% perubahan variabel terikat sedangkan sisanya sebesar 49,6\% diluar variabel peneltian ini.

Secara simultan didapatkan bahwa variabel bebas: location $\left(\mathrm{X}_{1}\right)$, marcandise assortments $\left(\mathrm{X}_{2}\right)$, pricing $\left(\mathrm{X}_{3}\right)$, costomer service $\left(\mathrm{X}_{4}\right)$, store design and display $\left(\mathrm{X}_{5}\right)$, dan communication mix $\left(\mathrm{X}_{6}\right)$ berpengaruh nyata terhadap variabel terikat Keputusan membeli $(\mathrm{Y})$ dengan nilai sig. 0,000 lebih kecil dari 0,05.

Variabel yang berpengaruh signifikan adalah Store design and display $\left(X_{5}\right)$ dan communication mix $\left(X_{6}\right)$ sedangkan empat variabel lainya tidak berpengaruh signifikan yaitu: location $\left(X_{1}\right)$, Marcandise assortments $\left(X_{2}\right)$ Pricing $\left(X_{3}\right)$ dan Costomer servic $\left(X_{4}\right)$.

\section{REFERENSI}

Gozhali, I. 2009. Ekonometrika Teori,Konsep dan Aplikasi Dengan SPSS 17, Jakarta: Erlangga.

Gilbert, D. 2003. Retail Marketing Management. Second Edition. London

Green, S.B. (1991). How Many Subjects Does It Take To Do a Regression Analysis? Multivariate Behavioral Research, 26, 499-510.

Mentri Perdagangan Republik Indonesia, 2008. Pedoman Penataan dan Pembinaan Pasar Tradisional, Pusat Perbelanjaan dan Toko Moderen. Peraturan Mentri Perdagangan.

Tambunan, T. (2004). Kajian Persaingan dalam Industri Retail. Komisi Pengawas Persaingan Usaha (KPPU).

Berman, B \& Evans, JR. (2010). Retail Management: A Strategic Approach (11th Ed.). New Jersey: Prentice Hall.

Ma'ruf, H. (2006). Pemasaran Ritel. Jakarta: PT. Gramedia Pustaka Utama

Levy, M \& Weitz, B.A. (2009). Retailing Management (7th Ed.). New York: McGraw-Hill Irwin.

Schiffman, I.G., \& Leslie L.K., 2004. Consumer Behaviour (8th Prentice Hall, New Jersey.

Suharyadi dan Purwanto, S.K. 2007. Statistika Untuk Ekonomi dan Keunagan Moderen Buku 2. Edisi 2. Salemba Empat. Jakarta 